\title{
The Renewal of Chinese Marxism: Debates over the Character of the Political Economy
}

JAMES FALKIN

\begin{abstract}
This is a study of those Chinese political economists and political philosophers in the early 1950s who sought to distance China's transition to socialism from the Soviet model for development. Writing for the leading economic and philosophical journals, Xin Jianshe [New Construction] and Xuexi [Study], these theorists attempted to apply Mao's 1937 call for a sinified Marxism to their contemporary reality by insisting upon a national strategy for socialist construction. Their arguments provided a source for the later break with the Soviet command economy. And it is the emphasis upon Chinese solutions to national problems that forms a line that connects this past with China's present.*
\end{abstract}

Keywords: state capitalism, new economy policy, sinification, cooperativization, transition to socialism, Soviet model.

\section{Introduction}

This is a study of the arguments of a group of party theorists in the early 1950s who insisted upon the uniqueness of China's socialist transition. Writing for the leading journals of Marxist political economy, Xin Jianshe [New Construction], and Marxist political philosophy, Xuexi [Study], these economists and philosophers insisted upon a contrastive path to the Soviet paradigm of development. Though it has been generally assumed that during this period China was simply following the Soviet model of a command economy (Schurmann 1966: 220-308; Teiwes 1993: 5-86), it was abandoned in the late 1950s. In fact, the search for a Chinese road to economic construction may be traced back to the reassessments of party theorists at the beginning of the decade.

In this search for a national definition of the political economy, these theorists sought to balance political and economic demands through a stress upon originality. It was in the early 1950s that a somewhat experimental approach to the economy, incorporating the market, was 
first advanced. In this regard there is a line of continuity between the past and China's present.

China's movement to a market economy has been a product of a nationalist approach. As has been noted, it has been neither founded nor guided by any well-established theory. China's movement from a planned to a market economy has been as experimental as it has been gradual and particularistic (Lin et al. 1996).

At the same time these economic reforms have continued to be defined (however loosely) within the more general vocabulary and framework of a transition to socialism. Though evidence suggests otherwise, there still is formal political adherence to a goal of a more advanced form of socialism. There is then an apparent tension between the exigencies of political legitimacy and the requisites of economic construction. Since the justification of communist rule may not be found in a capitalist economy, economic reforms have to be seen, officially at least, as part of something else: elements of a movement towards socialism.

It is to be expected that China's contemporary approach would be unique both as regards pace and direction. The search for 'real market socialism' suggests an originality to approach (Brus and Laski 1989). Yet within this distinctive strategy for growth there is an aspect of ideological continuity: there is a dialectic of continuity within discontinuity.

The early 1950s were also characterized by an attempt to define a political and economic programme of national design. This was the time when theorists first sought to create a consensus as to a national road within the strictures of ideology. Though it is clear that there has been a qualitative break in China with its economic past, it is important to look back at the arguments of party theorists in the early 1950s. To do so is to highlight a line of constancy where a nationalist perspective has always had to balance economic and political reality with the demands of the formal expression of purpose.

\section{'State Capitalism': The Tenet of Separation}

In 1953 the Chinese Communist Party declared a General Line on the Transition to Socialism (Mao 1977: 102). With an emphasis on first, the development of heavy industry at the expense of light industry and agriculture; second, on speed; and third a reliance on imported machinery, equipment and technical assistance from the Soviet Union, it seemed that China was following a Soviet path for economic development. This was the model of the command economy that had evolved from the 
particular circumstances of the Soviet Union in the late 1920s to become a general prescriptive pattern for growth (Brus and Laski 1989). ${ }^{1}$

Though Nicholas Lardy (1987: 160) asserts that the adoption of this model was surprisingly uncontroversial for the CCP, this was not the case. There was a group of political economists who were intent upon emphasizing the need for a gradual and specific approach to China's transition. These political economists drew a distinction between their contemporary moment and that of the Soviet Union during the early days of Lenin's New Economic Policy (NEP) in 1921. Their point of contrast was not with the origins of the command economy, rather they went back much earlier to the state capitalist policies of Lenin in order to highlight the particular character of China's underdevelopment. As Shen Zhiyuan, one of the three editors of New Construction wrote:

The fundamental nature of our country's political power and that of the Soviet Union is identical. However our country's historical conditions and those of the Soviet Union are not the same. Thus the form and function of state capitalism in our transition period and that which occurred in the Soviet Union are also different. (Shen 1953: 1)

It is important first to understand the idea of state capitalism in the NEP. The NEP was essentially an agricultural programme designed to stimulate the supply of basic foodstuffs and raw materials through internal trade. State regulation was to be relaxed as requisition was replaced by a tax-in-kind. Trade in general was to be conducted through the 'formation of an internal market' and the development of monetary exchange. Heavy industry was to be de-emphasized in favour of small industry, which would either be private or run as a cooperative. State enterprises were thus to compete with private traders and cooperatives through the market. As Lenin wrote in 1921:

Now the struggle between communist and private management is transferred to the economic plane, to the market, where nationalized industry, concentrated in the hands of the workers' state, must, by applying itself to the conditions of the market and to the methods of competition in it, win for itself decisive mastery. (Quoted in Carr 1950: 334)

This is what Lenin referred to as state capitalism: market capitalism under the power of the Soviet state.

Freedom and rights or cooperatives in present conditions in Russia mean freedom and rights for capitalism ... but 'cooperative capitalism', as distinct from private commercial capitalism is under Soviet power a species of state capitalism, and as such is beneficial and useful to us at present. (Ibid.: 336) 
The idea of state capitalism was critically important to China's political economists. They saw it as a starting point and as a portal through which they could develop a more extensive discussion concerning the state of the economy. As a general concept signifying the process of transforming capitalism into socialism, it could be traced back both to the Common Programme and to the Draft Constitution. Indeed Mao had characterized the economy in 1953 as state capitalist, and had talked of 'various' forms of state capitalism (Mao 1977). But it was unclear as to what he meant by all this, and it seemed at best simply a statement of fleeting significance. This certainly was not a description of an economic policy committed to rapid industrialization. Still, cloudy as it seemed to be, state capitalism was a legitimate political notion open to interpretation. And as those who wrote for New Construction were intent upon limiting the pace of economic reform, they read into this phrase a statement of complexity, a recognition of a lengthy process.

This was brought about through contrast, through the particularization of the universal. State capitalism became raised to the level of an abstract noun, a historic stage that all transitions were to pass through in a specifically determined manner. In this regard, uniqueness was made manifest through the particular function of state capitalism within each economy. Shen, for example, argued that whereas state capitalism was an external relationship in the Soviet Union, in China the relationship was internal: the state participated directly in the management of private enterprises:

The principal form of state capitalism that the Soviet Union adopted at that time [1921] was to follow a system of leasing and hiring. But today the principal form that our country adopts is one of public and private partnership. We do not lease or rent. (Shen 1953: 1)

At the same time, Qian Jiazhu stressed that while state capitalism in the Soviet Union acted as the mediation between small production and socialism, in China it served as the link between capitalism and socialism:

Can we compare our economy today [1954] with that of the Soviet Union in 1921? Without a doubt we consider we cannot. Although we are also a country where small production is supreme, we already have today a strong state economy and a rapidly developing cooperative economy. And from our state industrial enterprises and cooperative enterprises we have already established a link with the agricultural economy. Therefore our state capitalism is a transition from capitalist industry towards socialism, and is not a transition from small production towards socialism. (Qian 1954a: 38) 
Though China's economy might be more advanced than that of the NEP of 1921, it was still far too underdeveloped to emulate the Soviet command economy. 'At present,' Qian wrote, 'our economy is relatively backward' (Qian 1954b: 18). And thus both Qian and Shen fixed upon the concept of state capitalism, and interpreted it as a somewhat epochal process consisting of three lengthy stages. With respect to industry and capital accumulation, China was to move gradually from a situation where private capitalists were beginning to depend upon the state to that of an external alliance between the state and private capital, until that moment when the state would directly control all industry.

Concomitant with the development of the productive forces, there would be an evolution in the thinking guiding production. Ideological consciousness would grow with the improvements in technology.

It should be pointed out that going through the practice of state capitalism to transform private industry involves the transformation of private industry and the transformation of the private industrialist. These two aspects are unified and cannot be separated. The transformation of industry means going through each kind of state capitalism to make industry prosper, so that it is able to suit the needs of the national economy. To make, that is, industrial productive relations correspond to the developing requirements of the productive forces. The transformation of the individual occurs by going through state capitalism under the direct leadership of the socialist economic sector, to teach and transform the private industrialists, to make them become patriotic industrialists. (Qian 1954c: 16)

This sanguine approach to ideological reformation was shaped by a distinct view of the position of national capital in China. According to Qian, a violent struggle against this counter-revolutionary class was not necessary because these capitalists did not dream of restoration. Nurtured under the yoke of semi-feudalism and semi-colonialism, this specifically Chinese class was weak, and yet progressive in that it was willing to aid national construction. This was why they could be peacefully transformed (Qian 1954b: 16).

For Qian and Shen this point was critical because it underscored the uniqueness of China within the generality of the socialist experience. They argued that China might avoid the kind of forced liquidation of capital that had occurred in the Soviet Union.

The historical responsibility for the progressive transformation of state capitalism is the special responsibility of our socialist revolution. It did not previously exist in the Soviet Union, and it does not exist in today's Eastern European Democracies. (Qian 1954a: 38) 
The key here was the idea that difference was the necessary expression of the general prescriptions of Marxism. The universal truth that all socialist states needed to go through a transition to socialism only had meaning as the concrete, specific experience of each state. Qian was not trying to celebrate the achievements of China's economy in comparison to that of the Soviet Union at a similar stage of development; rather he was emphasizing the particularity of historical experience.

[It] severs the historical condition to quote a section from Lenin's 'On the Grain Tax' to try and explain the function of state capitalism in our transition period. Without question his analysis of the why and wherefore of small production is completely unsuited for our contemporary practice. (Ibid.: 39)

This stress on specificity was itself the reassertion of the cardinal principle of Maoist ideology: the sinification of Marxism. Mao's claim to power had been based upon the axiom that Marxism required a national form. As he said in 1938, at the 6th Plenum of the Central Committee:

What we call concrete Marxism is Marxism that has taken on a national form, that is Marxism applied to the concrete struggle in the concrete conditions prevailing in China, and not Marxism used abstractly ... Consequently, the sinification of Marxism - that is to say, making certain that in all of its manifestations it is imbued with Chinese characteristics, using it according to Chinese particularities - becomes a problem that must be understood and solved by the whole party without delay. (Schram 1989: 70)

The point here is that though Shen and Qian saw China's economy as far too backward to sustain a rapid drive for industrialization, and though they disagreed with the line of the 1st Five-Year Plan, their argument was, in its assertion of the need for an economic policy of national design, a restatement of the principle of sinification. Thus, while the CCP was formally accepting a foreign model for development, political economists, following from the tenets of Maoist ideology, were emphasizing that the meaning of Marxism was dependent upon a particular realization. As Shen wrote:

Within our life, within our practical struggle, according to this time here and now, in these concrete situations and conditions we adapt all workable methods. This is a matter for China's people themselves. The responsibility of creative Marxism is to utilize the ideological method of Marxism, based on the spirit and essence of Marxism, and unite it with China's concrete situation. (Shen 1953: 4)

This stress upon the particular seemingly implied a complete freedom to Marxist interpretation. The idea that meaning was dependent upon a specific realization clearly encouraged notions of subjectivity. And 
it was precisely to prevent voluntarism, and to see China's specificity in terms of economic gradualism that Shen began to re-emphasize the precepts of the objective laws of Marxism.

He used Stalin's 'law of correspondence' for socialist transitions (namely that the relations of production must always correspond to the level of the productive forces), to argue that China's economy needed to be overhauled in a steady and particular fashion. What he said was that the requirements of this law justified both a primary emphasis upon the development of the productive forces, and a prior transformation of these productive forces to make all this possible. In other words, he used this law to legitimate whatever he wanted.

He began by stating that the general line for the transition was based upon, 'the objective law and affirmation that the relations of production must be in conformity with the character of the productive forces' (Shen 1954: 11). This meant that, 'to realize the thorough transformation of the economic form, or to realize completely the transformation of the productive relations of each economic sector, it is necessary to strive to transform the technical conditions' (ibid.: 13). ${ }^{2}$ At the same time he wrote:

within our present small agricultural economy there is little possibility of being able to improve the situation of technology. The key determinant to such an improvement in agricultural technology lies in transforming the productive relations of the small agricultural economy; transforming the small agricultural system. (Ibid.: 18)

Shen, who had written on Hegel in the 1930s in Shanghai, knew that this argument was illogical. The relations of production may not precede the very level of the productive forces that they are supposed to suit. But what Shen was searching for in all of this was an injunction against subjectivism. 'Correspondence' had to signify restraint. 'In the end,' he said,

the line demands that under the prerequisite of the possible and the necessary there be a gradual process of going through each kind of state capitalism to realize gradually the socialist transformation of capitalist industry and commercial enterprises. This does not require, for example, the use of a paper law to nationalize immediately. (Ibid.: 18)

Shen's circular argument showed the difficulty of attempting to adapt the tenets of classical Marxism to what was, in these terms, an unanticipated situation. Whatever the spin of Stalin's law, it could not replace the axioms of nineteenth-century Marxism, with its stress upon the primacy of the productive forces. Yet in non-capitalist formations such as China in the 1950s, a stress on the determinacy of the productive forces 
undercut the party line that the transition to socialism would be guided by already existing socialist relations. To stress the backward level of the productive forces seemingly mocked the idea of a correspondence between base and superstructure. How could socialist relations suit an underdeveloped economic base? And yet to give meaning to the overall political line while offering recommendations as to course required that statements of substantive intent manoeuvre through a field of structural imperatives.

\section{The Singular Approach of the Translator of Marx's Capital}

Shen and Qian tried to manipulate the notion of objective law in order to put a brake on excess. The fear was that of a sudden chiliastic movement to try and transform the economic reality, a leap to create a Marxist rectification of names where socialist relations truly suited a newly realized socialist base. Their differences over policy, whether immediate in relation to the Soviet model for industrialization, or immanent in relation to the swing of voluntarism, were nevertheless expressed through the categorical framework of sinification. In this regard, it was to be expected that the injunction to adapt Marxism to China would lead to a more creative attempt than that of trying to balance objective law with economic reality. Instead moving within the same categorical framework, the next step would be to try and redefine the discourse of political economy in terms of novel constructs appropriate to its new moment. The idea would be to relocate the concepts and categories of political economy within new laws and contradictions. Ironically, or perhaps logically, it was the translator of Capital, Wang Xuewen, a member of the Central Committee and an editor of New Construction, who attempted to redefine the discourse of China's Marxist political economy.

The economy, Wang said, comprises five very loosely connected sectors. These included the socialist system of the state-owned economy, the semi-socialist system, the capitalist system of private ownership, the individual system of ownership, and state capitalism. In fact, they were basically self-sufficient entities governed by their own distinctive laws. 'The cooperative economy has its own principal laws, [and] the state-run economy has its own principal laws' (Wang 1954a: 35). There was no overall definition of the economy. Indeed he chastized those who 'see a link between each kind of sector in the transition period, but who do 
not recognize the particularity and the certain kind of independence of each kind of economy' (ibid.: 35).

The question was not one of emphasis, of stressing the parts rather than the whole. On the contrary, Wang was arguing that the nature of these sectors prevented a workable concept of unity. This meant that there could not be a fundamental economic law that could characterize this period. This was not an epoch or an era such as feudalism, capitalism or socialism. This was instead a moment distinguished by complexity, with a concomitant series of principal laws. And thus the state-run economy could not define the method or function of distribution and exchange in these other economies. 'There are those comrades,' Wang wrote, 'who do not recognize that the cooperative economy and the individual economy have their own economic laws' (ibid.: 35).

Because each economy has its own different conditions, the guiding function of the state-run economy receives, in one respect, the limitations and strengths of its [own] economic situation. At the same time, it also receives the limitations of other economic conditions. Although the state-run economy has as its basis the guiding economic laws of socialism, it certainly is not as it is in socialism where it constitutes the fundamental law determining the whole society. (Ibid.)

Wang's point was to try and redirect analysis towards what was truly specific abut this economy. This is why the denial of a fundamental law was so important, because it prevented the reincorporation of diversity within the more traditional nomenclature of capitalism and socialism. Instead, it focused concepts and categories upon China's present. To Wang, theorists who looked to the Soviet past to find a contemporary meaning for China failed to grasp the reality of China's uniqueness.

They do not understand that Lenin's analysis arose from concrete economic conditions. They do not understand that it indicated the transition to socialism. Our situation in the transition period is very complicated, and cannot be seen simply as a transition from capitalism to socialism, from these two kinds of constructs, each with its own [economic] tendency. It certainly does not summarize the five kinds of economic forms of our present. (Ibid.: 36$)^{3}$

Where Shen and Qian had compared China favourably in relation to the NEP, Wang saw China as lagging behind. And critically, this led him to argue that the party had misunderstood the entire character of the individual economy. It was not, he said, simply a small producing sector; it also comprised a large self-sustaining sector. The same terms were being incorrectly applied to what were in fact two distinct groups: one that produced for the market and one that tried merely to survive. 
'Within our small peasant economy there are two sectors whose characters are different and cannot be mixed ... it may not be said that the commodity producing sector has killed the naturally producing sector' (ibid.: 37 ).

This was a unique argument for a party theorist. To the degree that the party admitted that there was an individual economy, it was seen as a commodity-producing sector. Mao had noted that there were forms of communal ownership in China, but they were in the national minority areas (Mao 1977: 144). To suggest otherwise, to follow Wang's thesis that the individual economy was a complex economy in itself, independent of any overriding determination, undercut the idea of a rapid transition to socialism. The productive forces would have to be considered as far too backward to admit to anything other than a very gradual process of transition. Most importantly, and of immediate concern, to confuse a commodity-producing economy with a self-subsistent individual economy meant that the state would be purchasing grain from those who needed it to survive. The refusal to separate the subsistence and marketing sectors would mean that in the compulsory purchase of grain, the state would unknowingly extract that which many peasants needed simply to exist.

If one mistakenly believes that the small peasant economy is equivalent to small commodity producers, it will lead to the effect that there will be a purchase of residuary food stuffs, and a compulsory purchase of the daily intake of the peasant will be inevitable. (Wang 1954a: 37)

He was right. Within a year there was a grain supply crisis caused by the system of unified purchase (Lardy 1987: 162). ${ }^{4}$ After some time, the party admitted that there were cases where peasants did not have sufficient food. This was blamed on a variety of factors: cadre inefficiency, bureaucratism, and hoarding by rich and middle peasants (Bernstein 1969: 365-99). Clearly, this was also caused by the lack of an objective and detailed understanding of the countryside. Ultimately, it was far easier, and certainly politically more palatable, to see the small producing economy as coherent, whole and manageable, to see it as an element within the capitalist economy to be utilized, than to understand it as a primitive economic form subject to its own laws.

Wang's argument thus redefined the concept of transition in Chinese Marxism. The process now involved the transformation of a small producing sector and a subsistence-level economy.

Our country is not simply in a transition towards socialism but is still in transition from an individual economy towards socialism. Within our state economy, the individual economy occupies the moving force, and it is not 
simply a commodity producing sector. There are still many kinds of selfsufficient sectors. (Wang 1954a: 36)

In turn, this idea of the economy as a composite series of economies, each characterized by their own principal laws, seemed to suggest a need for new analytic constructs. The particularity of China's underdevelopment appeared to demand a more novel approach to Marxist political economy. This was after all, as was noted, Mao's call for a sinified Marxism. The problem for Wang, as it was for Shen and Qian, was that a stress on specificity not only risked endorsing voluntarism, it also seemingly detached China's road from the more general suppositions of a transition to socialism.

What Wang needed therefore was an economic sector that he could identify as either semi-socialist or socialist. This would permit him to emphasize a gradualistic process whereby he could locate China's unique situation within the more universal framework of Marxist economic precepts. This Wang found in the cooperative movement, which he characterized as semi-socialist. This allowed a subsistencelevel economy to be seen positively, to have a place within the Marxist continuum. Though specifically Chinese, the economy shared a more generally planned future as a socialist economy. This act of conceptual balance was brought about through contrast.

The transitional period in the Soviet Union had a primitive form of a small commodity agricultural economy. In our country this is the individual economy (it contains the natural economic sector and the small commodity sector). In the beginning of the Soviet Union's transition period, the cooperative economy was a state capitalist economy, afterwards it was a socialist economy. Our cooperative economy certainly is not a capitalist cooperative economy, and is not a state capitalist economy, but is a semisocialist and socialist cooperative economy. (Wang 1954b: 10)

Wang's concern was not with the extent of socialism within the cooperative movement. His point was that a new moment required new ideas. And this gave rise to and became the expression of more contemporary norms.

Marxist-Leninist political economy is without a study of semi-socialist cooperative economies. It is of course without a study of the laws of semisocialist cooperative economies. China's revolutionary practice created the semi-socialist cooperative economy. This kind of economy possesses its own economic conditions, naturally it produces its own laws. (Wang 1954a: 36)

To attempt to realize the consequences of particularism within original concepts threatened the discursive order. It stated that the intellec- 
tual moorings of the grid needed to be rethought. And to the degree that this could ever occur, this certainly was a prerogative of the elite. Moreover, the specific emphasis upon the complex status of the individual economy clearly undermined state intention, as this demanded a separate understanding of the transition to socialism. The irony was that this was precisely the kind of creative adaptation of Marxism that sinification presupposed.

Given that Wang was both a member of the Central Committee and the translator of Capital, his argument demanded a response. And in a long and considered article, 'Several Problems Concerning the Essence and Laws of Our Country's Transitional Period', two political economists, Du Ruji and Yu Shudong, restated a more orthodox position by arguing that Wang had misunderstood the character of the economy (Du and Yu 1954: 19).

$\mathrm{Du}$ and $\mathrm{Yu}$ began with the critical assertion that there was only one law governing the economy. Laws, they said, exist within a hierarchy, unified and defined by that which controls. One rules, the rest are ruled. 'And the ruling economy influences the other economies in such a way that they lose their independent developing character' (ibid.: 20). In the transition period, led by a unified Communist Party, the ruling sector was the socialist economy. It was thus to be seen as that which sharpened the antagonism between capitalism and socialism. Indeed, the very meaning of the transition was made manifest in the imposition of state will upon the private sectors.

As long as it was accepted that the socialist economy, or socialist economies, determined the complexity of unity, then clearly the contradiction with capitalism was the key to this period. Conversely, Wang's approach, his emphasis upon discrete laws and sectors, understated this antimony in favour of concomitant tensions. And it was this that $\mathrm{Du}$ and $\mathrm{Yu}$ found intolerable. 'If it is taken that in the transition period, each economic sector has 'its own principal laws', then by considering all these laws as equal, the struggle between fully developing socialism and dying capitalism is destroyed' (ibid.: 20). Wang had made a serious mistake: 'our transition period's particular contradiction is between socialism and capitalism' (ibid.).

This brought everything back to more familiar ground. It also restored the more conventional insights of Lenin and Stalin. And according to Du and $\mathrm{Yu}$, it was precisely the Leninist heritage that Wang had ignored. He 'exaggerates the distinction between China and the Soviet Union, and thereby destroys the universal significance of Lenin's proclamations 
concerning the transition period' (ibid.). Although China's particular form of underdevelopment required the stage of 'New Democracy', in terms of a macro view, especially with regard to commodity production in the countryside, China's situation was comparable to that of the Soviet Union in the late 1920s when rapid industrialization began.

The difference between the commodity production of our small agricultural economy and that of the Soviet Union at that time [1928] is not that great; thus, from the aspect of the individual economy the difference between the Soviet Union and us is one of degrees. It is not a qualitative difference. (Ibid.)

Everything depended upon how the individual economy was to be seen. Wang understood it as a separate economic sector with its own laws and character, while the more traditional view was that though a natural self-sustaining agricultural sector did exist as 'unsurmounted remains', they were too small to matter. Previously peasants treated produce as ground rent payable to the landlord, now this same produce became a commodity to be sold. Theoretically, the mistake was to see this category in absolute terms. 'It is not necessary to have a 100 percent commodity production to call an economy a small commodity economy' (ibid.: 21).

In turn, each position carried with it a severe consequence. For Wang, to ignore the obvious and instead to rely on shibboleths meant agricultural policies resulting in starvation: a grain crisis. To $\mathrm{Du}$ and $\mathrm{Yu}$, not to impose state will upon a commodity-producing economy engendered capitalism. For them this was the all-embracing conflict that characterized the whole transition process.

We must guide the individual peasant economy towards socialism, and not allow its spontaneous development towards the road of capitalism. And it is because the individual economy is a small producing economy that in the transition period we utilize the circulation of commodities to promote trade between the state and cooperative societies, promote the circulation between town and country, and strengthen the alliance between workers and farmers. (Ibid.: 22)

Wang's attempt to recast the theoretical discourse so that it might be more appropriate to its political reality opened up the possibility for a different commitment to the idea of socialism. This represented both an achievement and a threat. For the effect of grounding the principle of specificity in a federated economic base was to demand the postponement of all substantive discussion regarding the transition as a somewhat immediate and recognizable goal. But this denied the very certainty which was not only an assumed right of state, but which had already 
been summarized and classified in the Constitution. The state of the individual peasant economy had already been officially defined.

Wang's argument was unique and prescient. At the same time he also shared with his colleagues on New Construction an approach that stressed the particularity of China's experience. In this regard, their ideas represented a direct line to Mao's speech at the 6th Plenum in 1937. For the first time since the seizure of power there was now substantive theoretical support for the belief that China's transition was fundamentally a matter for the Chinese people themselves.

\section{The Political Philosophers Weigh In}

Political economists offered critical interpretations of the economic base. Their concern was less with the political and ideological superstructure than with the complexity of economic definition. But in order to develop their points, these economists had to adopt the basic discursive framework of Chinese Marxist political theory. This was the categorical ground that shaped the attempts at conceptual breakthrough of those who wrote for the journal New Construction. In this regard, Wang's argument represented a decisive effort at shifting that ground at a categorical level. Whatever the success or failure in this regard, these economists had contributed to moving the argument back to the specificity of China.

In this they were not alone. Political philosophers were also arguing over the character of this political economy and over the suitability of Soviet models. And corresponding to discussions of the base, these ideological controversies were expressed through a conceptual framework that emphasized the particularity of Chinese Marxism. To make this clearer, it is important to look at the major dispute among political philosophers as to the nature of this transitional political economy.

The question of the state of this political economy was the subject of a bitter argument which took place in the Marxist-Leninist Institute over two years, 1953-55, between two philosophers, Ai Siqi and Yang Xianzhen. The two basic paradigms that they offered represented two opposing lines as to where China was, and how it could and should develop socialism.

Yang Xianzhen saw the base as a unity, as a whole constructed from the sum of its productive relations. 'The theory of the sum total of the relations of production is that there are all kinds of productive relations, and these co-exist at the same time' (Yang 1981a: 11). In turn, each pro- 
ductive relation was composed of three aspects: the form of ownership over the means of production; the method of exchange; and distribution. But in themselves these did not constitute a separate or quasi-independent system. Irrespective of difference or complexity, each productive sector was simply an element within the general order.

Within a society where the exploiters have not yet vanished, the 'base' itself just has the character of synthesis. To deny the character of synthesis to the transitional period is without basis, because Marx was very clear that the base was the social economic form. And the social economic form is the sum total of the productive relations. And is not the sum total synthesis. (Yang 1981b: 57)

If Marx is the arbiter here, the answer is no. Marx was writing from the stance of capitalism, analysing its dialectical underpinnings. He made it clear that in its beginning phase capitalism contained pre-capitalist economic formations. But as there had been a qualitative change in the dominant mode of production, these 'unsurmounted remains' only survived in a transfigured way.

Bourgeois society is the most developed and the most complex historic organization of production. The categories which express its relations, the comprehension of its structure, thereby also allows insights into the structure and relations of production of all the vanished social formations out of whose ruins and elements it built itself up, and whose partly still unconquered remnants are carried along within ... [S]ince bourgeois society is itself only a contradictory form of development, relations derived from earlier forms will often be found within it only in an entirely stunted form, or even travestied. For example, communal property. (Marx 1973: 105-6)

In this regard, Marx's emphasis on the dynamic of continuity and discontinuity, his promised dictum of ineluctable economic change and conflict, seemingly had little in common with Yang's view of a static, integrated economy of equal parts.

As China's economy had been officially characterized in terms of five productive relations, it was these forms that Yang understood to be the base. 'In the end the social economic formation of our transitional economy is constituted from five kinds of economic sectors' (Yang 1981b: 42). And quoting from the 7th Plenum of the 7th Party Congress, he listed them as:

1. the socialist system of the state-owned economy

2. the cooperative or semi-socialist system of ownership

3. the capitalist system of private ownership

4. the system of individual ownership

5. state capitalism. 
This was where he saw China to be at present. Concerning the achievement of socialism, he thought that the key lay with the extraordinary potential of the peasantry, particularly in their ability to forge a creative alliance with state industry. Indeed he went so far as to see this sector, which he also referred to as the individual economy, as the basis for socialist construction: 'In the practice of the transitional period, small agriculture must be the foundation of the socialist state' (ibid.: 48). And in this argument he found support from Lenin and Stalin:

Lenin and Stalin were very clear on this point. In the transitional period, before collectivization, to build a socialist economic basis meant uniting agriculture and industry into one integrated economy, subordinating agriculture to the leadership of socialist industry or using the products of large-scale industry to exchange for the products of the peasants. This agriculture referred to is individual agriculture and the peasants referred to naturally are individual peasants, not a collectivized peasantry. (Ibid.: 47)

In light of what followed in the Soviet Union, this celebration of the pre-collectivized peasantry is somewhat odd. And of course, irrespective of historical circumstance, it is strange to find a Marxist panegyrize the peasantry. But it is perhaps less mystifying when it is made clear that for Yang, existence implied acceptance. The real was simply nothing more than the rational expression of immediately recognizable truth. 'That is to say, we must honestly recognize the world as it is, by its true colours: is thus is, is not thus is not, the earth just is the earth, to have just is to have, and to be without just is to be without' (Yang 1955a: 147). Thus the peasantry, the largest sector in the economy ('quite clearly, straight through till today, within our agriculture, individual agriculture still occupies the tendential force') had to be the foundation of what he saw as an integrated economy (Yang 1981b: 47). The predominant part of the whole had to be understood as the basis of that whole. To suggest otherwise, moving towards an emphasis upon antagonism and conflict, would have undermined his principle of synthesis.

But here the philosophical underpinnings of this idea are less important than the fact that he felt that this argument had historical precedent. Yang believed that China's present was actually contemporaneous with the early stages of the NEP. And therefore he relied on Lenin's On Co-operation, which set the policy for the socialist transformation of agriculture in 1921, to justify the concept of the composite base.

In On Co-operation Lenin argued that since the working class controlled the means of production and monopolized political power, the basis of agricultural production should be peasant cooperatives. These voluntary institutions, which he had previously labelled as 'petty-bourgeois', but 
had now been raised to a 'third type of commercial enterprise', were to be seen as the foundation of socialism.

The power of the state over all large-scale means of production; political power in the hands of the proletariat, the alliance of this proletariat with the many millions of small and very small peasants, the assured proletarian leadership of peasantry, etc. - is this not all that is necessary to build a completely socialist society out of cooperatives; out of cooperatives alone which we formerly ridiculed as huckstering ...? It is still not the building of socialist society, but it is all that is necessary and sufficient for it. (Lenin 1975: 708)

It is not clear how serious Lenin was about this. As Moshe Lewin notes, Lenin had a tendency to connect the idea of socialism to any pressing task in order to motivate the populace (Lewin 1975: 95). When electrification was the target, for example, socialism was defined as 'Soviet power plus electrification'. And thus it is possible to see the identification of socialism with cooperatives as an exaggerated attempt to mobilize the peasantry. Yang nevertheless took Lenin's words as a statement of principle for the transitional strategy:

Lenin's theory of co-operativization was the guiding principle for the movement of the labouring peasants towards socialism. It was the most important ideological weapon of the party and the government in the work of advancing the socialist transformation of the small peasant economy. It was the basis of the party's policy towards the peasants. (Yang 1955b: 2)

Most importantly, Yang argued that underlying Lenin's conceptualization was the affirmed tenet of synthesis, the belief in the seemingly inviolate link between the sectors. It is this that allowed for a somewhat blithe attitude towards the non-socialist sectors. Otherwise, in the sense of real class struggle, they would have to be seen as potentially counter-revolutionary, demanding suppression through, for example, collectivization. 'Lenin recognized that within the enterprise of socialist construction, the principle of socialist transformation is that the organizational parts cannot be split' (ibid.: 2).

Since Yang also assumed that state power in China was secure, it seemed clear that China's peasantry should serve as the rallying point for the transition. This now non-threatening class could be trusted to support all state efforts. In addition, what Yang saw as Lenin's tolerance of self-interest among the peasantry seemingly endorsed a somewhat static view of them. Cooperatives offered a gradual controlled process, in which personal gain could be combined with the overall good of the collective. Their value was that they were not an imperative for quick change. 
Lenin considered that in the transition to socialism, all cooperative systems, especially the agricultural system were the easiest form for the individual peasant to receive and understand ... It was the best form to unite private interest with that of the whole. (Ibid.)

This theme of social assembly, where state control mitigates conflict, was in turn extended by Yang to the private and semi-capitalist sector. As with peasant cooperatives, so the policy towards industry was to be a mixed form, a state capitalism, where ultimately profit and activity would be determined by the state. 'Our present policy towards the capitalist industry of "utilize, restrict and transform" ... is the concrete utilization in China of the policy which Lenin pointed out concerning state capitalism' (ibid.).

In arguing that rural policy should be seen in terms of the requirements of the peasantry, in particular the individual peasant, and that industry should adopt a state capitalist form, Yang felt that he had captured the essence of Lenin's transitional programme. In this regard, with his stress on the NEP and state capitalism, he was clearly echoing the arguments of those who were writing for New Construction. At the same time, in general Yang could also be seen as following the line of Bukharin. Though Yang did not talk of 'ultimately riding into socialism on the backs of the rich peasantry', and though he did not discuss the principle of equilibrium, the downgrading of class struggle, the idea of a 'third form' of production, placed Yang firmly within a Bukharinist approach. And in this, in historically parallel fashion, Yang shared an interpretation that separates Lenin from the later history of collectivization (Cohen 1975, chapters 4-9).

This is significant because it represents a change that had occurred in Chinese political discourse. The former understanding of Soviet history as a complete model was now superseded by a view that saw Soviet history discretely, as relatively independent moments offering different sources for recommendation. Yang could not possibly have been unaware of the Stalinist collectivization campaign, and yet he chose simply to ignore it. And that he did so makes clear the lifting of any sense of prohibition to do otherwise. The logic that salvages Lenin by divorcing him from later practice is here founded upon an analysis that defines all of the Soviet past as basically data to be separated out for conceptual support. It is a reason that has confidently moved beyond one particular form of categorical imperative. Though Yang's analysis was clearly out of the mainstream in respect to Soviet orthodoxy, this created no problem for him in China. The discursive territory had shifted. In Maoist terms, the arrow of Marxism was now falling on Chinese ground. 
This use of Soviet history as citation for more novel interpretation may also be seen in the writings of Yang's main philosophical and political opponent Ai Siqi, who was one of the leading editors of Xuexi [Study], and Zhexue Yanjiu [Philosophical Research]. Ai was a theorist of revolution. Whereas Yang seemingly legitimized his reality through somewhat circular reasoning - what is should be; and it should be, because it is - for $\mathrm{A}$, all moments were historically conditional, factors within an ongoing process. Within this historical flux there was a centre of gravity, this was the transcendent idea of socialist construction. Thus all events could be broken up into a contingent relation, as to whether or not a given economic sector aided or obstructed the transition to socialism. China's economies would now be defined in terms of whether they aided or obstructed a socialist base.

What does our State have as its own economic base? Is it formed simultaneously of the four different systems of ownership, or is it formed only of the productive relations of the system of whole people's ownership, and the system of collective ownership that are being established? (Ai 1964: 6)

Ai's question was not what was real; rather it was what was real for socialist construction? This meant that while capitalism and the individual peasant economy were part of the transitional period, they were not part of the base. The problem with Yang's argument, Ai said, was that Yang misinterpreted supervision for acceptance.

In order to utilize the productive forces of capitalism, it was necessary ... to show adequate concern for its productive relations, but it would be a mistake to think that this amounts to regarding capitalist relations as our own economic base. (Ibid.)

To Yang this was apparently inexplicable, since it excluded that which was obviously there. And this is why he asked rhetorically: 'How do socialists eat? Do they not depend upon the very produce of those peasants whom they seemingly ignore?' (Yang 1981b: 50). But to Ai this was an equally fatuous question, because it was empirical. His concern was with the realization of an idea. The state helped the peasants out of need, 'for the purpose of obtaining material supplies from their productivity ... and not because we want to consolidate and develop their productive relations' (Ai 1964: 10).

This restriction of the concept of the economic base to the relations of production was critically important because it provided a theoretical justification for a socialist transition within conditions of underdevelopment. By narrowing the definition of the economy to the state of its productive relations, to its political or administrative situation, thereby 
removing the forces of production and technology from the equation, $\mathrm{Ai}$ was now able to explain how socialist relations could precede economic development, and continue to direct the economy. The more traditional idea that a socialist transition presumed an achieved level of productivity was here replaced by an insistence that ultimately the state determined the character of the economy.

The reduction of the economy to its productive relations allowed $\mathrm{Ai}$ to regroup the various forms of ownership into the two antagonistic bases of socialism and capitalism.

The economy of the transition period is transitional ... because the socialist base is only in the course of its formation. In its midst there still exists the capitalist base, though this base is steadily declining and dying. (Ibid.: 5)

Non-socialist economies or non-socialist forms of ownership stood in relation to the socialist economy as productive forces, as instruments of production. They existed simply as use-value. 'Not everything which we can and must manage is the economic base of our state regime, and only that which we have to form and consolidate can be our own economic base' (ibid.: 9).

The emphasis was thus on transformation, upon supplanting that which was. In this regard, his argument followed the party line in seeing the command economy and rapid industrialization as the key to construction. Indeed he saw China's situation as analogous to that of the Soviet Union in the late 1920s when, as he understood it, class struggle was rife (Ai 1954: 3).

It helps to recall that during this time in China there were a number of ongoing campaigns to eradicate 'counter-revolutionaries' and 'classcollaborationists'. The Sufan movement to purge anti-party elements, the excoriation of Hu Feng and the idea of 'bourgeois humanism', and the start-up of the criticism of Liang Shuming and the philosophy of pragmatism, lent support to the idea that this was a period characterized by antagonistic contradictions. The Gao Gang affair had only recently been resolved, and as Mao had noted, this was a manifestation of 'intense class-struggle at the present stage' (Mao 1977: 155).

To Ai, the method to overcome class conflict seemed clear: collectivization and a concentration upon heavy industry. This is the way that Stalin 'defended and developed Lenin's thoughts on socialist industrialization' (Ai 1954: 4). This policy continued to be appropriate, Ai said, because in China heavy industry is the 'pivot capable of driving all socialist industrialization forward' (ibid.). At the same time, collectivization was the foundation of industrialization. Though 
collectivization was Stalin's specific response to the grain crisis, it still had general application.

Stalin pointed out that in developing the construction of socialist industry, it's necessary to guide the individual peasant in an orderly fashion towards the road of collectivization, to construct a socialist basis in the villages. (Ibid.).

To refer to the Soviet collectivization campaign as orderly was designed to reassure a domestic audience that adaptation did not suggest exact duplication. Not even the strongest supporters of rapid industrialization were suggesting that China reintroduce a Soviet-style forced collectivization. And other than setting out what might be called the general laws of entry into socialism, viz. collectivization and industrialization, Ai had little to say concerning detailed economic or political strategy. This is not surprising; as a political philosopher his central concern was more with the role of consciousness in shaping the material base than it was with a detailed analysis of the political economy.

In this regard, the fact that he did not simply repeat the basics of the Soviet method was significant. It represented further evidence that theorists were now assuming the new categorical ground of China's specificity. At the conceptual level, in the arena of explanation, analysis and suggestion, where controversies attempted either to endorse or to anticipate the 'correct line', Soviet experience had a definite place. It offered evidence for dictums, and proof for contentions. This is why Soviet history could be broken up so easily into a series of periods, each almost a clear and discontinuous moment, for their use-value was determined by China's theorists. Ai and Yang could each have their Lenin and their Stalin. The statements of Lenin and Stalin were thus citations, references for policy recommendations. Indeed the principle of difference was so rooted in China's political discourse that Ai had to reassure his readership that this did not imply an abandonment of socialism.

Our present line for the transition period has its own particularity, and is distinct from the general line for the transition period in the Soviet Union. Nevertheless both are concerned with the transition to socialism. Therefore it may not be said that because China's general line for the transition is possessed of its particularity, and is dissimilar to that of the Soviet Union, it is not a general line for the transition to socialist society. (Ibid.)

The stance of particularism had created its own equivalent truths within the worldview of Marxism-Leninism. 


\section{Conclusion}

It is now clear that during the period when China was following Soviet economic strategy, Mao was having serious doubts as to its efficacy. Indeed, his argument for a more balanced approach, signified by the 'Ten Great Relationships' marked the beginning of a break with the Soviet approach. As he said in 1955 in presenting the 'Ten Great Relationships' to ministers: 'It made a start on proposing our own line for construction' (Mao 1958: 101). Economically, the desire to look inward could be traced in part to a general disappointment with the slow pace of agricultural growth (Lardy 1987: 160-74). This frustration led in part to the famous speed-up in collectivization in 1955-56, which was almost immediately followed by a movement to reverse its excesses (ibid.). But this break with the Soviet model had of course a more longstanding source, namely Mao's enmity towards the Soviet Union (Schram 1989). Without going through the entire history of this stormy relationship, here it may simply be noted that his rise to power had ultimately come at the expense of the 'Returned Students' from Moscow. This was the context for Mao's speech of 1937 emphasizing the sinification of Marxism.

In this regard, Mao's nationalist ideas in the mid-1950s fell on a ground that was shared or had already been worked by political economists and philosophers. It was not that he followed them, indeed intellectually they followed him; their arguments were the realization of his call for Chinese Marxism. But it might be suggested that the theories of those who wrote for New Construction and the political philosophers formed a tributary that flowed into a stream of thought that was insistent that China's future was a matter for the Chinese people themselves. The argument was that the Soviet model of a command economy was ill suited to China's reality. The point of contrast with Lenin's NEP programme of state capitalism made it clear that for theorists such as Shen Zhiyuan, Qian Jiazhu and Wang Xuewen, China's transition demanded a road of specific design. And it is this stress on national solutions to national problems that forms a line that connects this past with China's present.

James Falkin is Adjunct Assistant Professor of Political Science at the College of Staten Island, City University of New York. 


\section{NOTES}

* The author would like acknowledge the contributions made by the anonymous reviewers.

1 On the changing character of the command model, see Brus and Laski (1989, chapters 4-7).

2 'Somewhat surprisingly, the adoption of a Soviet-style big push industrialization strategy involving massive resource mobilization for manufacturing and neglect of agriculture does not appear to have been controversial within the CCP. Here there is no evidence that prior to the 1st FYP there was anything approaching the industrialization debate in the 1920s in the Soviet Union, which pitted E.A. Preobrazhensky's theory of a 'big push' industrialization program against N.I. Bukharin's theory of balanced growth of industry and agriculture.' (Lardy 1987).

3 The discussion above is drawn from Carr (1950).

4 Lardy dates the beginning of the crisis to 1953. 'There were several symptoms of that crisis, but these can be traced primarily to a single cause-state intervention in grain marketing.' (Lardy 1987).

\section{REFERENCES}

Ai Siqi 1954. 'Xuexi Sidalin De Xueshuo Wei Zai Woguo Jianshe Shehuizhuyi Shehui' [Study Stalin's Theory of the State In our fight to Construct Socialist Society], Xuexi [Study] 3: 3-5.

- 1964. 'In Refutation of Comrade Yang Hsien-chen's "Composite Base Theory". Selections from China's Mainland Press, Nov. 6, 1966, no. 3337: 3-12.

Bernstein, Thomas P. 1969. 'Cadre and Peasant Behavior under Conditions of Insecurity and Deprivation: The Grain Supply Crisis of the Spring of 1955.' In A. Doak Barnett (ed.), Chinese Communist Politics in Action. Seattle: University of Washington: 365-99.

Brus, Wlodzimierz, and Kazimierz Laski 1989. From Marx to the Market. Oxford: Clarendon Press.

Carr, E. H. 1950. The Bolshevik Revolution, vol. 2 1917-1921. Middlesex: Pelican Books.

Cohen, Stephen F. 1975. Bukharin and the Bolshevik Revolution. New York: Vintage Press.

Du Ruji and Yu Shudong 1954. 'Guanyu Woguo Guodu Shiqi Jingji Xingzhi He Jingji Faze De Jige Wenti' [Several Problems Concerning the Essence and the Laws of Our Country's Transitional Economy], Xin Jianshe [New Construction] 12: 19-26.

Lenin, V. I. 1950. 'On State Capitalism.' In E. H. Carr (ed.), The Bolshevik Revolution, Vol. 2 1917-1921. Middlesex: Pelican Books.

- 1975. On Co-operation Quoted in R. Tucker (ed.), The Lenin Anthology. New York: W. W. Norton Press: 707-14.

Lardy, Nicholas 1987. 'Economic Recovery and the 1st Five Year Plan.'. In R. MacFarquar and J. K. Fairbank (eds), The Cambridge History of China, Vol. 14. Cambridge: Cambridge University Press: 144-85.

Lewin, Moshe 1975. Political Undercurrents in Soviet Economic Debates. London: Pluto Press.

Lin, Justin Yifu, Fang Cai and Li Zhou 1996. The China Miracle: Development Strategy and Economic Reform. Hong Kong: Chinese University Press.

Mao Tse-Tung 1958. 'Talks at the Chengtu Conference' quoted in S. Schram (ed.), Mao Tse-Tung Unrehearsed: Talks and Letters 1956-71. Middlesex: Penguin Books.

- 1977. Selected Works Vol. 5. Peking: Peking Language Press. 
Marx, Karl 1973. Grundrisse. Foundations of the Critique of Political Economy. Trans. Martin Nicolaus. Middlesex: Penguin Books.

Qian Jiazhu 1954a. 'Zai Lun Guojia Zibenzhuyi Jingi De Wenti' [Again on the Theory of State Capitalism]. Xuexi 8: 37-40.

- 1954b. 'Zhonghua Renmin Gongheguo Xianfa Cao'an Yu Shehui Jingii Zhidu' [The Draft Constitution of the People's Republic of China and the Socialist Economic System]. Xin Jianshe 8:13-20.

- 1954c. 'Lun Guojia Zibenzhuyi' [On the Theory of State Capitalism]. Xin Jianshe 2: 11-17.

Schram, Stuart 1989. The Thought of Mao Tse-Tung. Cambridge: Cambridge University Press.

Schurmann, Franz 1966. Ideology and Organization in Communist China. Berkeley: University of California Press.

Shen Zhiyuan 1953. 'Guanyu Guojia Zibenzhuyi De Xingzhi Wenti' [Concerning the Character of the Problems of the State Capitalist Economy]. Xin Jianshe 12: 1-6.

- 1954. 'Zong Luxian Yu Shenchan Guanxi Yiding Yao Shihe Shengchanli Xingzhi De Faze' [The Law of the General Line that the Relations of Production Must Conform to the Character of the Productive Forces]. Xin Jianshe 4: 11-18.

Teiwes, Frederick C. 1993. 'The Establishment and Consolidation of the New Regime.' In R. MacFarquhar (ed.), The Politics of China 1949-1989. Cambridge: Cambridge University Press: 5-86.

Wang Xuewen 1954a. 'Guanyu Woguo Guodu Shiqi De Jingi Faze Wenti' [Questions Concerning the Economic Laws in Our Transition Period]. Xuexi 7: 35-39.

- 1954b. 'Xianfa Cao'an Yu Woguo Guodu Shiqi De Jingi' [The Draft Constitution and our Transitional Economy]. Xin Jainshe 9: 7-10.

Yang Xianzhen 1955a. 'Liening Guanyu Guodu Shiqi De Xueshuo' [Lenin's Theory of the Transition State]. Renmin Ribao [People's Daily], March 22.

- 1955b. 'Siwei Dui Cunzai De Guanxi Zhege Zhexue Shang Zui Genben De Wenti Ye Shi Women Yiqie Shiji Gongzuo Zhong Zui Genben De Wenti' [The Relationship between Thought and Existence Is the Most Fundamental Problem in Philosophy]. Zhexue Yanjiu [Philosophical Research] 2: 138-56.

- 1981a. 'Guanyu Zhongguo Xin-Minzhuyi Shehui De Jichu Yu Shangceng Jianzhu De Wenti' [Concerning the Problem of the Base and the Superstructure in China's New Democracy]. In Yang Xianzhen, Wo De Zhuxue 'Zui'an' [The Details of my 'Criminal Philosophy']. Beijing: 3-29.

- 1981b. 'Guanyu Zhonghua Renmin Gongheguo Zai Guodu Shiqi de Jichu Shangceng Jianzhu De Wenti' [Concerning the Problem of the Base and the Superstructure in the Transitional Period of the People's Republic of China]. In Yang Xianzhen, Wo De Zhuxue 'Zui'an'. Beijing: 29-61. 